Eduvest - Journal of Universal Studies

Volume 1 Number 11, November 2021

p- ISSN 2775-3735 e-ISSN 2775-3727

\title{
CORRELATION AND DISPERSION OF MARINE DEBRIS TO MOLLUSCA IN THE INTERIDAL ZONE
}

\author{
Eugenius Alfred Renjaan, Dortje Theodora Silubun, Dullah Irwan Latar, Marvin \\ Mario Makailipessy, Megawati Elisabet Juley \\ Tual State Fisheries Polytecnich, Southeast Maluku Regency, Indonesia \\ E-mail: earenjaan@polikant.ac.id, nona.silubun@gmail.com, irwan.latar@gmail.com, \\ mariomarvin.mm@gmail.com, megawatielisabetjuley99@gmail.com
}

\begin{tabular}{|c|c|}
\hline ARTI & ABSTRACT \\
\hline $\begin{array}{l}\text { Received: } \\
\text { October, 26 } \\
2021 \\
\text { Revised: } \\
\text { November, } 17^{\text {th }} \\
2021 \\
\text { Approved: } \\
\text { November, } 19^{\text {th }} \\
2021\end{array}$ & $\begin{array}{l}\text { The research was carried out on Langgur Beach from } \\
\text { January to March 2021. The purpose of this study was to } \\
\text { determine the correlation and dispersion of marine debris } \\
\text { to molluscs in the Intertidal Zone of Langgur Beach, the } \\
\text { edge of the Rosenberg Strait, Kei Islands, Indonesia. The } \\
\text { data collection method of this research is the quadratic } \\
\text { method. The results of the study noted that the total } \\
\text { marine debris accumulated at } 21 \text { sampling points } \\
\text { amounted to } 7,596 \text { items consisting of } 14 \text { categories of } \\
\text { marine debris and } 6 \text { species of Mollusca were found. The } \\
\text { results of the analysis show that the dispersion of surface } \\
\text { marine debris and marine debris in the sediments are } \\
\text { scattered in groups, the dispersion per type of } \\
\text { macrozoobenthos on the surface and in the sediments is } \\
\text { scattered in groups, regularly and randomly. The results of } \\
\text { the analysis also showed a positive correlation between } \\
\text { marine plastic debris on the sediment surface and the } \\
\text { bivalves of Gafrarium pectinatum on the sediment } \\
\text { surface. }\end{array}$ \\
\hline KEYWORDS & $\begin{array}{l}\text { Langgur Beach Intertidal Zone, Marine Debris, Mollusca, } \\
\text { Gafrarium Pectinatum }\end{array}$ \\
\hline c) (P) & $\begin{array}{l}\text { This work is licensed under a Creative Commons } \\
\text { Attribution-ShareAlike } 4.0 \text { International }\end{array}$ \\
\hline
\end{tabular}

Eugenius Alfred Renjaan, Dortje Theodora Silubun, Dullah Irwan Latar, Marvin Mario Makailipessy, Megawati Elisabet Juley (2021). Correlation and Dispersion of Marine Debris to Mollusca in the Interidal Zone. Journal Eduvest. 1(11): 1341-1356

How to cite:

E-ISSN:

Published by: $\quad$ https://greenpublisher.id/ 


\section{Eugenius Alfred Renjaan, Dortje Theodora Silubun, Dullah Irwan Latar, Marvin Mario Makailipessy, Megawati Elisabet Juley}

\section{INTRODUCTION}

Indonesia is the second producing country for marine plastic debris after China and marine plastic debris that enters the sea area, it is known to be 12.7 tons per year, where most of the marine debris comes from land activities and is expected to continue to increase by 50 to 250 tons in 2025 (Jambeck et al., 2015).

Marine debris is a persistent solid object produced by humans directly or indirectly by being dumped or left at sea. The amount of marine debris is increasing and almost 60 to $80 \%$ of marine debris consists of plastic. Plastic is a common consumption of modern society, most of the plastic consumption is only used once. As a result, piles of plastic debris will pollute the environment and become marine debris (Wang, Tan, Peng, Qiu, \& Li, 2016). Currently marine debris is one of the most worrying global environmental issues because of its high impact on ecosystems, human health, and the economy. Most marine debris consists of plastic, wood, metal containers, and fishing gear (nets, ropes, buoys, etc.). which is a material that is expected to remain afloat on the surface for some time, be extended or sink to the bottom (Beaumont et al., 2019).

Marine debris increases and has a wider impact. Any accumulation of marine debris on the beach is a function of wind direction and beach orientation, while the source of marine debris comes from coastal residents who throw garbage directly to the beach, and are carried away by currents and waves from other locations and other areas, apart from the waste from transportation facilities. between islands, ships (ferries) and fishing vessels, as well as from seaweed cultivation activities using ropes and plastic bottles (Renjaan, Silubun, Latar, \& Makailipessy, 2020).

The composition of waste generated from human activities is organic waste as much as 60 to $70 \%$ and the rest is non-organic waste 30 to $40 \%$. types of plastic bags or crackles other than plastic packaging_(Purwaningrum, 2016). Based on data from Plastic Europe (2016), the current global annual plastic consumption has reached more than 300 million tons with the highest production being in the last decade. Research reveals the crisis regarding marine debris continues to increase with no signs of diminishing ((Jambeck et al., 2015); (Boucher \& Friot, 2017). If this situation continues, it is expected that the amount of plastic accumulated will double from 2010 to 2025, increasing from about 8 million metric tons in 2010 to 9 million tons in 2015, and to 16 million tons in 2025 (Mortillaro, 2017).

Marine debris generally results from anthropogenic activities. This is a direct threat to marine habitats, coastal ecosystems, human health and navigational safety, resulting in serious socio-economic losses. Common examples of marine debris are plastic, organic matter, metal, glass, rubber and other solid waste.

NOOA (2016) states that the results of research on marine debris found in all waters in the world, the type of plastic debris is the most common type and is often found and has the potential to have an impact on marine organisms.

Molluscs are one of the constituents of marine ecosystems that have diversity

species are tall and spread in various marine habitats. Mollusc life is generally influenced by the quality of the waters, including the type of substrate, habitat, $\mathrm{pH}$, temperature and salinity (Pratiwi \& Ernawati, 2016).

Mollusca can be found from coastal areas near the coast to the deep sea, occupying coral reef areas, some immerse themselves in the substrate or sediment, some can be found attached to marine plants. Molluscs can live on a variety of substrates, including sandy, rocky and muddy substrates, besides that, molluscs also have high adaptability to places and weather (Triwiyanto, Suartini, \& Subagio, 2015).

Phylum mollusca is the phylum with the second largest number after Arthropoda. 
Mollusca consists of seven classes, namely: Polyplacophora, Gastropods, Bivalves, Scaphopoda, Cephalopoda, Aplacophora and Monoplacopora. The two largest classes of the mollusc phylum are Gastropods and Bivalves (Candri, Junaedah, Ahyadi, \& Zamroni, 2018).

Marine debris is found and scattered in groups from macro to meso sizes around the coast of Langgur city, as the western edge of the Rosenberg strait, the kei islands. Marine debris is thought to have influenced the life of marine biota, for example molluscs that settled around the Langgur beach. There is not much information about the relationship between marine debris and mollusc abundance on the Langgur beach, so we wanted to explore this information. The purpose of this study was to determine the correlation and dispersion of marine debris on molluscs in the intertidal zone of Langgur beach, Kei Islands. Indonesia. The results of this study are expected to be information about the impact of marine debris correlation on molluscs, as well as important information for marine debris management on the Langgur beach, Kei Islands.

\section{RESEARCH METHOD}

The location of this research is Langgur Beach, a beach on the west bank of the Rosenberg Strait in the Kei Islands, Indonesia. The tools used include: Transect quadratic measuring 1 meter $\mathrm{x} 1$ meter, soil $\mathrm{pH}$ meter, refractometer, thermometer scale $0^{\circ} \mathrm{C}$ to $100^{\circ} \mathrm{C}$, shovel, needle sitting scale (capacity 50kg), GPSmap76CSX, sieve eye size $2 \mathrm{~mm}$, petri dish (size $100 \mathrm{ml} \times 20 \mathrm{ml}$ and $80 \mathrm{ml} \times 15 \mathrm{ml}$ ), digital gram scale, permanent marker, stationery, camera, rubber gloves, scissors, $1 \mathrm{~cm}$ ruler, rubber band, sample bottle, loop, laboratory oven, tweezers, shoes boot, dropper pipette, graded sieves measuring $1 \mathrm{~mm}$, 500 micrometer, 300 micrometer, 200 micrometer, 100 micrometer, and a digital scale. The materials used include: tissue, water, plastic containers, trash bags, aluminum foil, plastic bags, label paper, plastic samples, plastic jars, raffia rope, plastic spoons, spray bottles, measuring cups measuring $250 \mathrm{ml}$ and $10 \mathrm{ml}$, aquades and $10 \%$ alcohol.

Sampling begins with a survey of the research site, then proceeds with determining the sampling point as well as preparing tools and materials. Sampling was carried out at low tide based on the Global Tide tidal application from January to March 2021. Measurements used the $1 \mathrm{~m} \times 1 \mathrm{~m}$ quadratic transect method. Sampling was done randomly.

Correlation and dispersion analysis between marine debris and mollusc density scattered at 21 sampling points on Langur beach using descriptive statistics frequencies analysis to determine the distribution pattern of a species in each sampling square using SPSS software.

Information :

$$
\mathrm{I}=\frac{\mathrm{S} 2}{\overline{\mathrm{X}}}
$$

$\mathrm{I}=$ dispersion index

S2 = Variance

$(\mathrm{x})=$ Mean

Meanwhile, to analyze the correlation using Pearson bivariate correlation analysis where to measure the strength and direction of the linear relationship of two variables using SPSS software.

$$
\mathrm{r}=\frac{\sum x y-\frac{\left(\sum x\right)\left(\sum y\right)}{n}}{\sqrt{\left(\sum x^{2}-\frac{\left(\sum x\right)^{2}}{n}\right)\left(\sum y 2-\frac{\left(\sum y\right)^{2}}{n}\right)}}
$$


Where $: r=$ correlation value

$\mathrm{x}=$ variable $\mathrm{x}$

$\mathrm{y}=$ variable $\mathrm{y}$

The strength of the correlation relationship, according to D.A de Vaus 2002 as follows:

-0.00 : No relationship

- $0.01-0.09$ : The relationship is less meaningful

- 0.10 - 0.29 : Weak relationship

- 0.30 - 0.49 : Moderate relationship

- 0.50 - 0.69 : Strong relationship

- $0.70-0.89$ : Very strong relationship

$\bullet>0.90$ : Close to perfect relationship.

\section{RESULT AND DISCUSSION}

A. Distribution of Sediment at Sampling Locations in the Intertidal Zone of Langgur Beach

The results of measurements of sediment samples carried out at 21 sampling points have medium sand and coarse sand categories, with the highest percentage of $61.94 \%$ found at point 3 and the lowest percentage found at point 13 of $21.96 \%$.

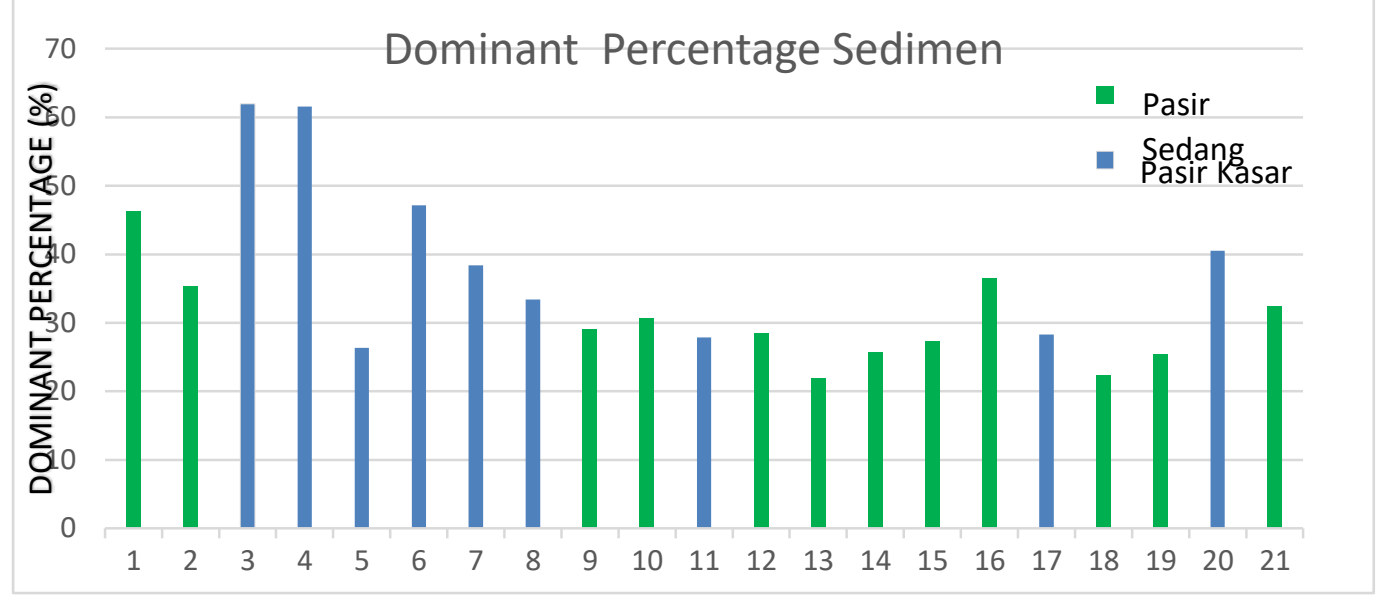

Figure 2. Distribution of sediment at the sampling location in the intertidal zone of the Langgur pantai coast

The results of the measurement of sediment samples at the research site found the types of sediments of coarse sand (coarse sand) and medium sand (medium sand). Coarse sand has a grain size of 26.34 - 61.94, while medium sand has a grain size of $21.96-$ 46.26.

Gemilang et al., (2018) stated that the difference in sediment grain size is related to the origin of the sediment source. The closer to the mainland the grain size of the sediment tends to be finer, while the grain size facing the open sea is coarser. This shows that the sediment source comes from the sea which then undergoes a transportation process until it is finally deposited into sediment at each location.

1. Some Oceanographic Factors at the Sampling Site

a. $\mathrm{pH}$ Measurement Results

Measurement of the $\mathrm{pH}$ value at 21 observation points has a constant value with a $\mathrm{pH}$ value of 7 presented in Figure 3 


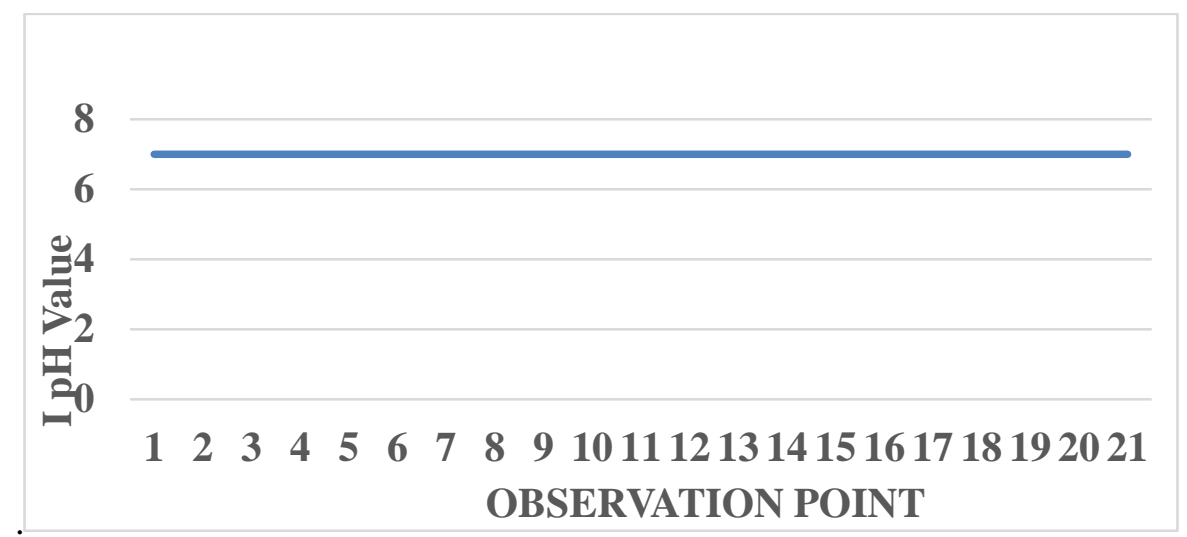

Figure 3. pH value

The results of $\mathrm{pH}$ measurements at the Langgur beach have a relatively neutral and stable $\mathrm{pH}$ value, which is constant 7. Salim et al., (2017) which says that the ideal pH value for waters is 7 to 8.5 . (Siwi et al., 2017) said that the high and low $\mathrm{pH}$ is an important factor to control the activity and distribution of organisms that live in the waters.

b. Temperature Measurement Results

Measurement of temperature values at 21 observation points has a temperature value ranging from $28^{\circ} \mathrm{C}$ to $35^{\circ} \mathrm{C}$ with the highest temperature found at sampling point 6 and point 7 while the lowest temperature is found at point 10 and point 11 is presented in Figure 4 ..

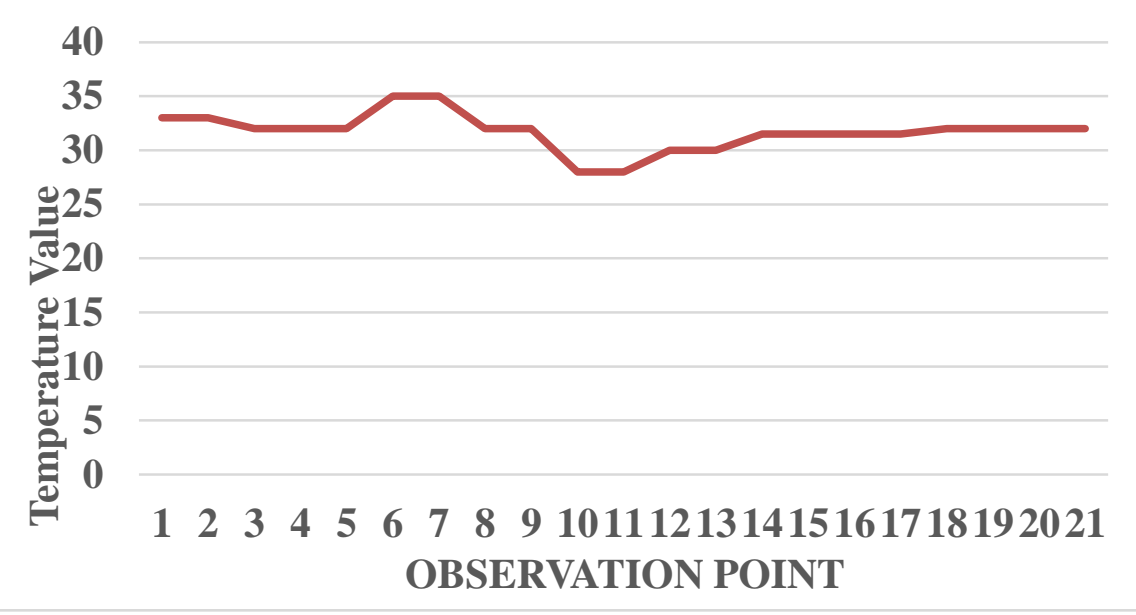

Figure 4. Temperature value

The results of temperature measurements at Langgur beach have values ranging from $28^{\circ} \mathrm{C}$ to $35^{\circ} \mathrm{C}$. The temperature value of $28^{\circ} \mathrm{C}$ was found at point 10 and point 11 , this happened because the measurement process was carried out after rain and the weather was cloudy, causing the temperature value at point 10 and point 11 to be low while the temperature value of $35^{\circ} \mathrm{C}$ was found at point 6 and point 7, this happened because the measurement process is carried out during hot weather, causing the temperature values at point 6 and point 7 to be high. This is in accordance with the opinion of Priosambodo (2016) which states that the normal temperature that allows organisms to live, grow and reproduce and spread, is between temperatures below $0^{\circ} \mathrm{C}$ to $33^{\circ} \mathrm{C}$. 


\section{Eugenius Alfred Renjaan, Dortje Theodora Silubun, Dullah Irwan Latar, Marvin Mario Makailipessy, Megawati Elisabet Juley}

c. Salinity Measurement Results

Salinity ranges from values of 25 to 35 with the highest salinity found at sampling points $8,12,13,14,15,16,17,18,19,20$ and 21 while the lowest salinity was found at points $4,5,10$ and 11 presented at picture..

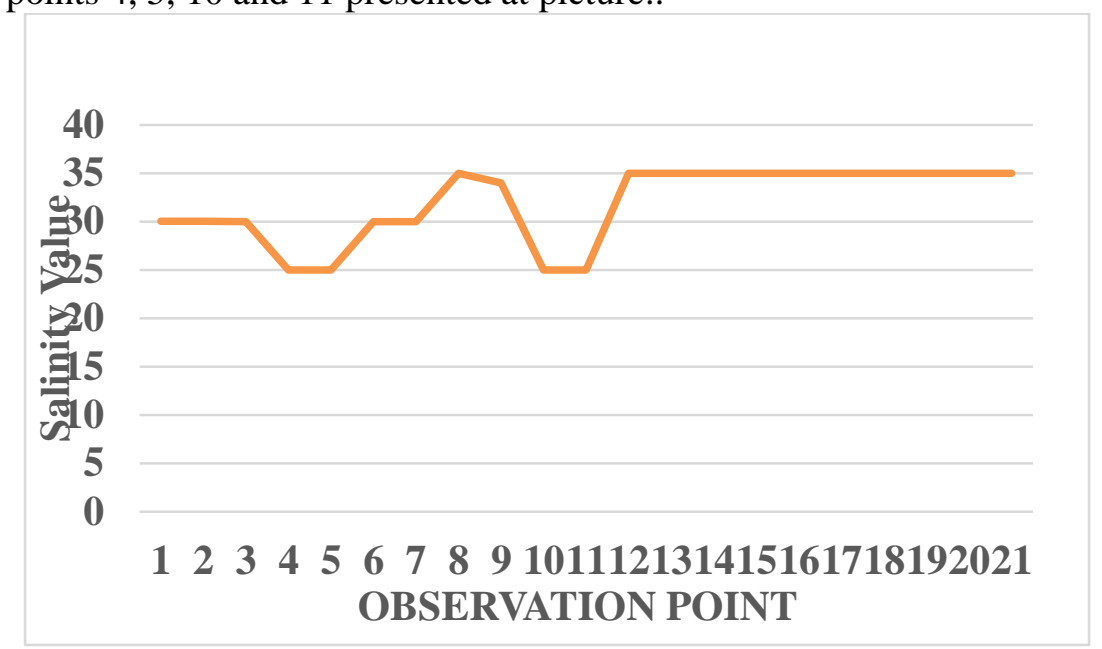

Figure 5. Salinity Value

The salinity measurement results have values ranging from 25 to 35 . Salinity values of 25 are found at points $4,5,10$ and 11, this happens because the measurement process is carried out after the rain and points $4,5,10$ and 11 are points close to the waste disposal from several houses in the observation location, causing the salinity value at the observation point to be low and included in brackish water while the salinity value of 35 was found at points $8,12,13,14,15,16,17,18,19,20$ and point 21 , this happens because the measurement process at that point is carried out during hot weather and the point is close to the sea, causing the value to be high and classified as sea water. This is supported by the opinion of Dewi (2017) which states that low salinity values in waters will affect the distribution pattern of organisms such as animals belonging to the phylum mollusca, which can survive in conditions of $25-35 \%$ salinity.

2. Density and Type of Marine Debris

a. Surface Sea Debris

According to the results of the study, samples of surface sea debris at 21 research points resulted in a total of 1699 items $/ \mathrm{m} 2$ of marine debris per point. Surface sea debris has 13 categories of marine debris found at 21 research points including: general goods, consumer plastics, plastic packaging, fishery marine debris, plastic remnants, foamed plastic goods (polystyrene), other materials, glassware and ceramics, cloth goods, metal goods, rubber goods, wooden goods, and auxiliary goods. The most marine debris was found at point 5 and point 11 with a total amount of marine debris 166 items $/ \mathrm{m} 2$, while the least amount was found at point 17 with a total marine debris of 30 items $/ \mathrm{m} 2$. Surface sea debris is dominated by plastic debris around $83 \%$. The category of marine debris that dominates is the category of plastic remains, while the category of paper and cardboard goods is not found at all points. 


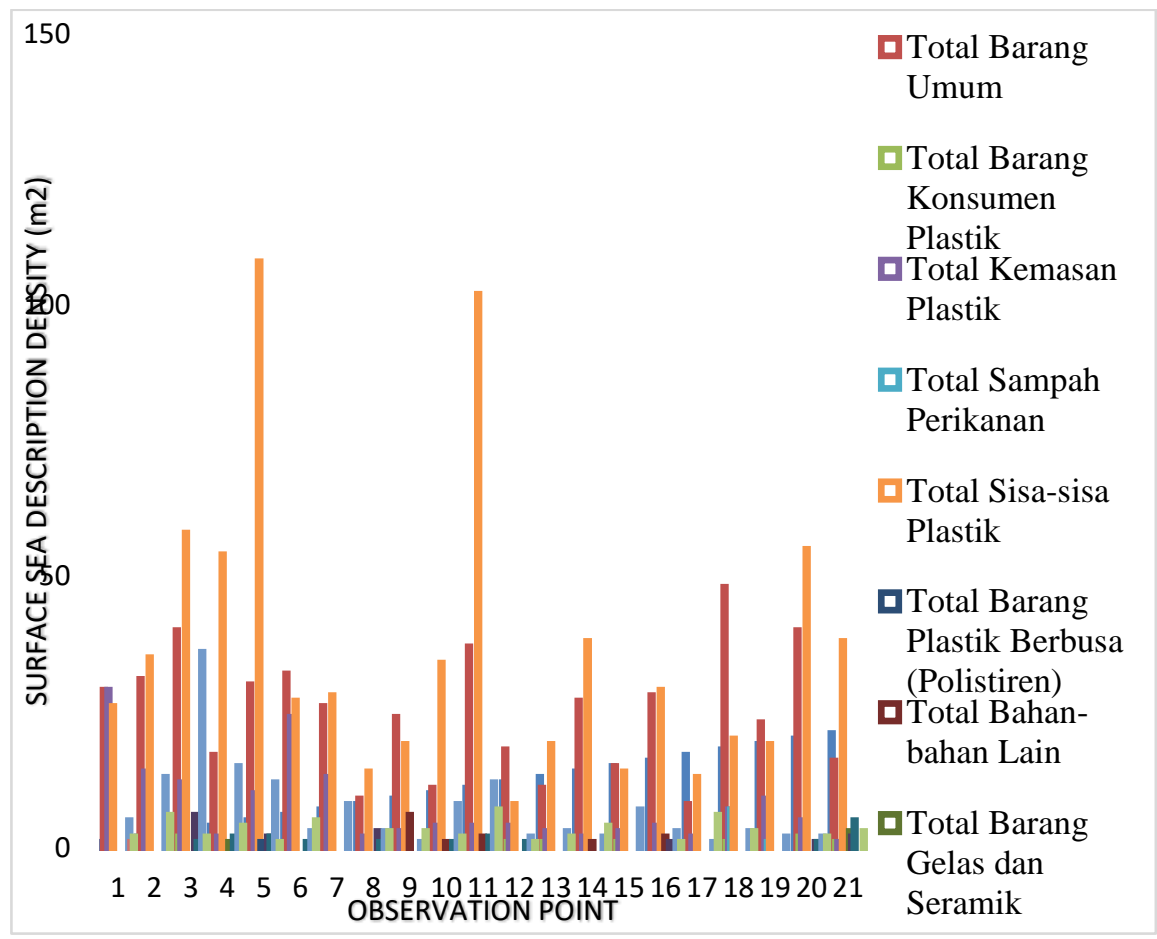

Figure 6. Density and type of marine debris (items/sqm) on the beach surfacei

The results of the research on surface sea debris showed that there were various types of marine debris found and the type of marine debris remaining from plastic was the most common type found at point 5 with a total of 108 items $/ \mathrm{m} 2$ and point 11 with a total of 102 items $/ \mathrm{m} 2$. Surface marine debris is dominated by plastic debris around $83 \%$. Plastic is the dominant marine debris because plastic is a pollutant that has been globally distributed in all waters due to its durable and buoyant nature (Zhukov et al 2017; Djaguna, 2019). The amount of plastic in the ocean originates from and is influenced by activities and the number of human populations, such as in areas with high population numbers, namely China and Indonesia (Jambeck et al., 2015; Zhukov, 2017). Seawater pollution that cannot be avoided by human waste is human-generated debris, according to research results (Jambeck et al., 2015) saying that Indonesia is a country ranked second in the world for plastic debris to the sea which reaches 18.2 million tons per year. . From a number of existing marine debris, it is estimated that around $60 \%$ to $80 \%$ of marine debris consists of plastic. Plastic accumulates in the oceans due to its continuous use. Disposal from ships has been estimated at 6.5 million tonnes of plastic per year. (Leberton, et al., 2017).

\section{Marine Debris in Sediment}

According to the results of the study, samples of marine debris in sediments at 21 sampling points resulted in a total of $5897 \mathrm{items} / \mathrm{m} 2$ of marine debris per point. Marine debris in sediment has 13 categories of marine debris found at 21 sampling points including: general goods, consumer plastics, plastic packaging, marine fisheries debris, plastic scraps, foamed plastic goods (polystyrene), other materials, glassware and ceramics, cloth articles, metal articles, rubber articles, wooden articles, and auxiliary goods. The most marine debris was found at point 5 with a total amount of marine debris 


\section{Eugenius Alfred Renjaan, Dortje Theodora Silubun, Dullah Irwan Latar, Marvin Mario Makailipessy, Megawati Elisabet Juley}

545 items $/ \mathrm{m} 2$, while the least amount was found at point 17 with a total marine debris of 35 items $/ \mathrm{m} 2$. Marine debris in the sediment is dominated by plastic debris around $91 \%$. The category of marine debris that dominates is the category of plastic remains, while paper and cardboard goods are not found at all points.

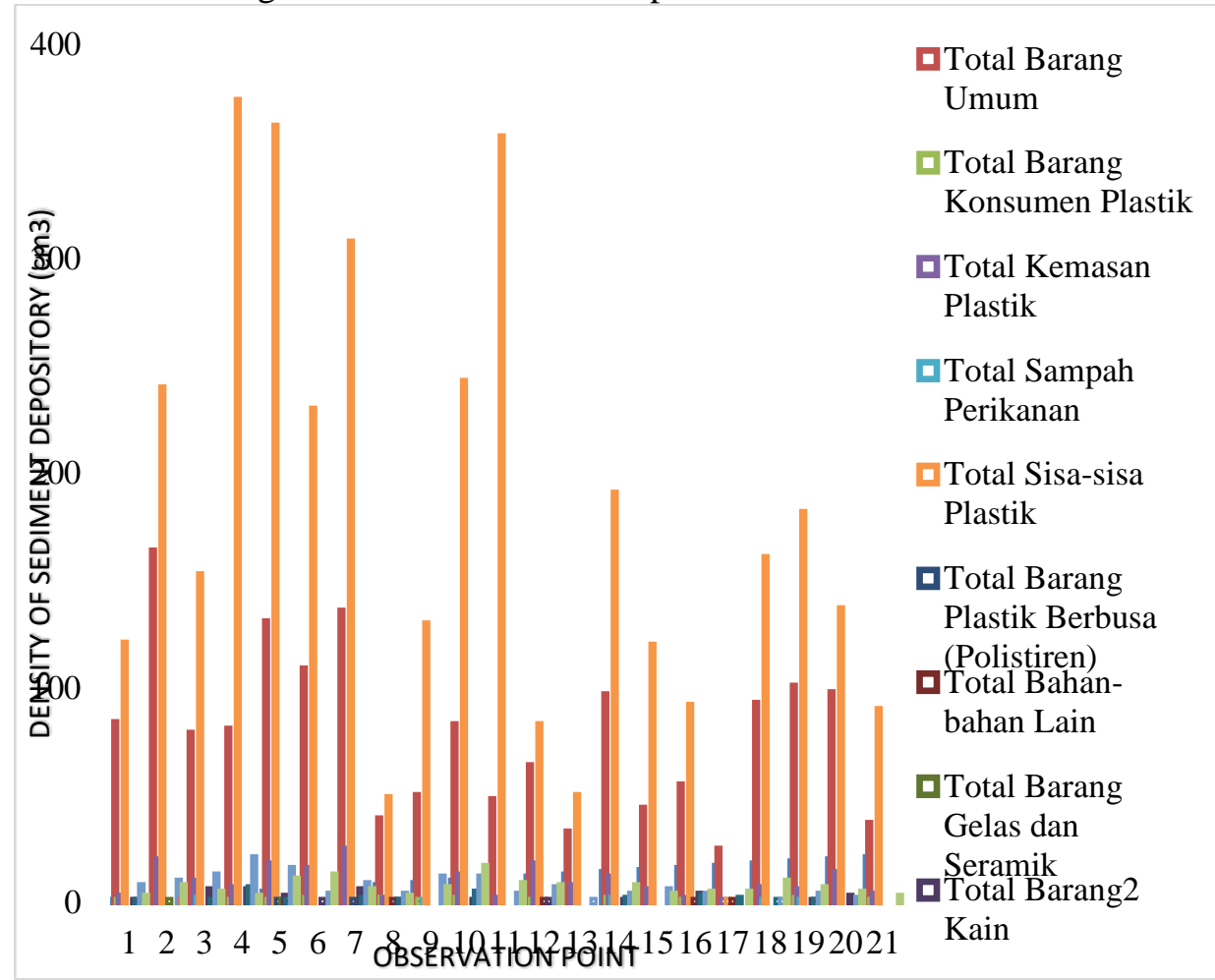

Figure 7. Density and type of marine debris (items/square meter) in sediment

The results of marine debris research in sediments showed that there were various types of marine debris found and the types of marine debris plastic remnants were the most common type found at point 4 with a total of 374 items $/ \mathrm{m} 2$, point 5 with a total of 362 items $/ \mathrm{m} 2$ and point 11 with a total of 357 items $/ \mathrm{m} 2$. Marine debris in the sediment is dominated by plastic debris around $91 \%$. Marine debris in sediments is dominated by plastic debris because marine plastic debris is debris that is difficult to decompose. Galgani et al., (2015) which said that almost 95\% of water and seabed debris is dominated by plastic type debris, from the total debris accumulated along the coastline to the seabed is one of the particles that are difficult to decompose in water. Plastics are widely used in human activities including households because of their benefits as patent containers that are waterproof and easy to use, which appear in the form of plastic packaging or on electrical appliances and household appliances (Arifin, 2017).

Plastic packaging debris and household utensils are types that are often encountered in everyday life with their nature that are difficult to degrade in nature, this debris is categorized as the largest contributor of waste and causes damage to the balance (Hiwari et al., 2019).

\section{B. Total Surface Molluscs and Deep Molluscs}

1. Total Mollusca Surface Per Point At Sampling Location

The results of the study found that the total surface molluscs per point were 419 individuals $/ \mathrm{m} 2$. The most common species found was Cerithidea cingulata as many as 78 
individuals $/ \mathrm{m} 2$ found at point 19 while the least species found were 2 species having the same number, namely Nerita undata as much as 1 individual/m2 found at points $3,8,14$, and 17 and Anadara antiquata as much as 1 individual $/ \mathrm{m} 2$ was found at point 5 and point 13.

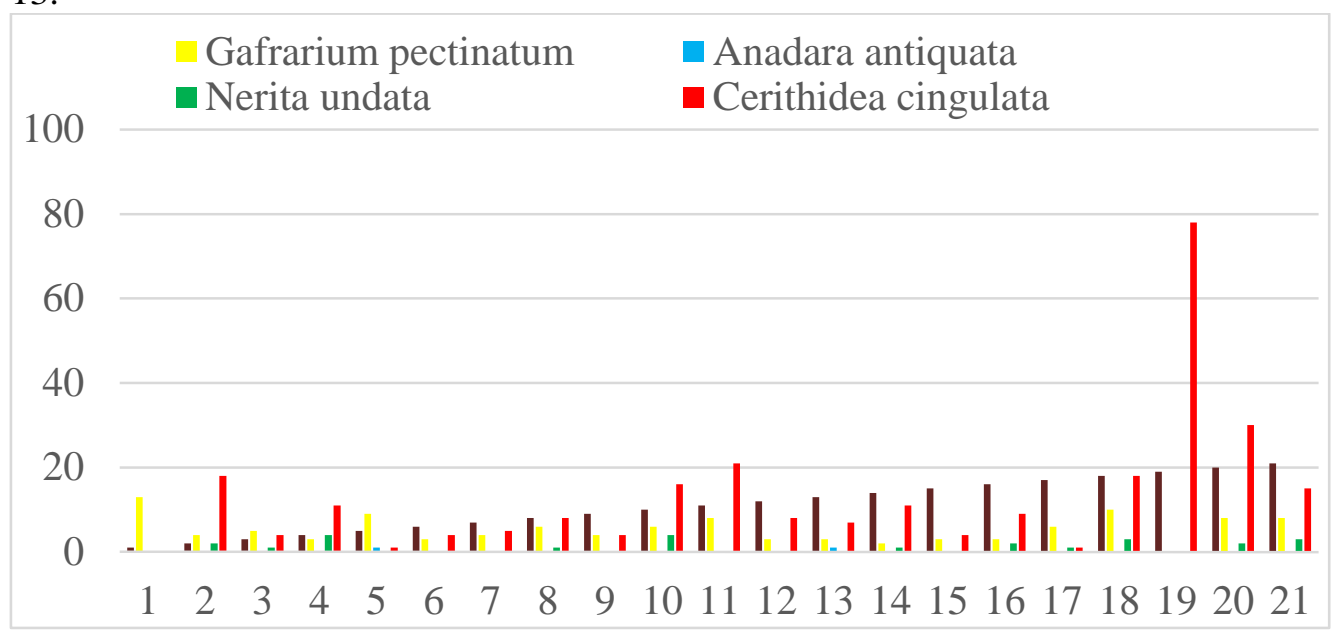

Figure 8. Total surface molluscs per point in the intertidal zone of the Langgur pantai coast

The results of Figure 8 show that the surface mollusc phylum consists of 2 classes found at the research site, namely the bivalves class and the gastropod class. Bivalves consist of 2 species, namely Gafrarium pectinatum and Anadara antiquata, while gastropods consist of 2 species, namely Nerita undata and Cerithidea cingulata.

The high and low number of molluscs and variations in the number of individuals of each species are caused by disturbances or pressures from the environment, this situation explains that only certain species can survive. The uneven number of individuals for each species is related to the adaptation pattern of each mollusc, such as the availability of various types of substrates, food, and environmental conditions. This is evidenced by the presence of several individual gastropods and bivalves that dominate certain places. The highest number of gastropods was Cerithidea cingulata species at 78 individuals $/ \mathrm{m} 2$ while the lowest was Nerita undata species at 1 individual $/ \mathrm{m} 2$. The highest number of bivalves was the Gafrarium pectinatum species as many as 13 individuals $/ \mathrm{m} 2$, while the lowest was the Anadara antiquata species as many as 1 individual $/ \mathrm{m} 2$. This causes the difference in the number of gastropods and bivalves obtained at the study site at each point to differ greatly. Wahyuni et al., (2017) stated that if all species have relatively the same or almost the same abundance and no large dominance is found, the diversity is high, so that the diversity value at the study site will be a reflection of each species being spread relatively evenly in number.

\section{Total Mollusca In Sediment Per Sampling Point}

The results of the study found that the total molluscs in the sediment per point were 456 individuals $/ \mathrm{m} 3$. The most common species found was Gafrarium pectinatum as many as 28 individuals/m3 found at point 9 while the least species found 4 species had the same number, namely Anadara antiquata as much as 1 individual $/ \mathrm{m} 3$ found at point 9 and point 10, Cypraea annulus had a total 1 individual $/ \mathrm{m} 3$ was found at point 1 , Nassarius reticulatus as much as 1 individual/m3 was found at point 1 and point 21 , Nerita undata as much as 1 individual $/ \mathrm{m} 3$ was found at points $2,4,7,8$, and 13 . 


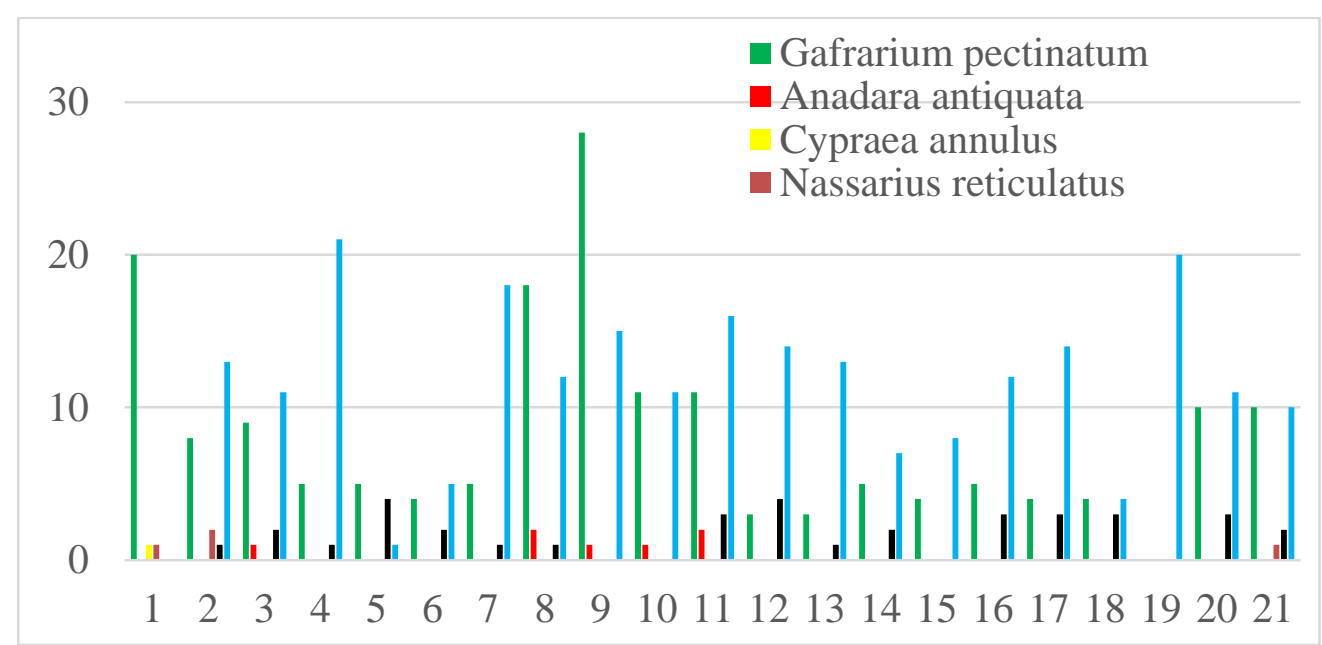

Figure 9. Total molluscs in sediment per sampling point in the intertidal zone of the Langgur pantai coast

The results of Figure 7 show that the phylum mollusca in the sediment consists of 2 classes found at the study site, namely the bivalves class and the gastropod class. Bivalves consist of 2 species, namely Gafrarium pectinatum and Anadara antiquata, while gastropods consist of 4 species, namely Cypraea annulus, Nassarius reticulatus, Nerita undata and Cerithidea cingulata. The high and low number of molluscs and variations in the number of individuals of each species are caused by disturbances or pressures from the environment, this situation explains that only certain species can survive. The presence of molluscs at the study site was also caused by the availability of the type of substrate, food, and environmental conditions. This is evidenced by the presence of several individual gastropods and bivalves that dominate certain places. The highest number of bivalves was Gafrarium pectinatum at 28 individuals $/ \mathrm{cm} 3$ while the lowest was the Anadara antiquata species at 11 individuals $/ \mathrm{cm} 3$. The highest number of gastropods was Cerithidea cingulata species as many as 21 individuals $/ \mathrm{cm} 3$, while the lowest was 4 species, namely Cypraea annulus 1 individual $/ \mathrm{cm} 3$, Nassarius reticulatus as many as 2 individuals $/ \mathrm{cm} 3$, Nerita undata as many as 14 individuals $/ \mathrm{cm} 3$ and Cerithidea cingulata as many as 21 individuals $/ \mathrm{cm} 3 \mathrm{~cm} 3$. This causes the difference in the number of gastropods and bivalves obtained at the study site at each point to differ greatly. Zarkasyi et al., 2016) which states that the diversity index of a species does not only depend on the number of individuals found, but is also determined by the uniformity index of a species in the community.

3. Classification of Mollusca (Bivalves and Gastropods)

The results of research conducted in the intertidal zone of the Langgur coast found 6 families and 6 species of molluscs, which are presented in the following table:

Table 2. Taxonomy of Molluscs

\begin{tabular}{|l|l|l|l|l|l|l|}
\hline $\begin{array}{l}\text { Kingd } \\
\text { om }\end{array}$ & $\begin{array}{l}\text { Filu } \\
\mathrm{m}\end{array}$ & Class & Ordo & Family & Genus & Spesies \\
\hline \multirow{2}{*}{$\begin{array}{l}\text { Anim } \\
\text { allia }\end{array}$} & \multirow{2}{*}{$\begin{array}{l}\text { Moll } \\
\text { usca }\end{array}$} & \multirow{2}{*}{ Bivalvia } & Veneroida & Veneridae & Gafrarium & $\begin{array}{l}\text { G.pectinatu } \\
\text { m }\end{array}$ \\
\cline { 4 - 7 } & & Gastropoda & Cycloneritida & Neritidae & Nerita & N.undata \\
\cline { 3 - 7 }
\end{tabular}




\begin{tabular}{|l|l|l|l|l|}
$\mid$ & $\begin{array}{l}\text { Caenogastrop } \\
\text { oda }\end{array}$ & $\begin{array}{l}\text { Potamidida } \\
\mathrm{e}\end{array}$ & Cerithidea & C.cingulata \\
\cline { 2 - 5 } & $\begin{array}{l}\text { Littorinimorp } \\
\text { ha }\end{array}$ & Cypraeidae & Cypraea & C.annulus \\
\cline { 2 - 5 } & $\begin{array}{l}\text { Neogastropo } \\
\mathrm{da}\end{array}$ & Nassariidae & Nassarius & $\begin{array}{l}\text { N.reticulat } \\
\text { us }\end{array}$ \\
\hline
\end{tabular}

1. Dispersion Analysis of Surface Sea Debris and Deep Sea Debris Sediment From the data obtained from the sampling of surface marine debris and marine debris in sediments at 21 points, the dispersion test of surface marine debris and marine debris in sediments is scattered in groups..

Table 3. Analysis of Surface Debris Dispersion Index and Deep Sea Debris Sediment

\begin{tabular}{|l|l|l|l|l|}
\hline Dispersion Test & Variance & Mean & I & Description \\
\hline Surface Sea Debris & 1714.7 & 80.9 & 21.1 & Group \\
\hline Marine Debris in Sediment & 21056.4 & 280.8 & 74.9 & Group \\
\hline
\end{tabular}

The results of the dispersion analysis show that surface marine debris and marine debris in sediments have a value where $\mathrm{S} 2 / \mathrm{x}>1$ so that surface marine debris and marine debris in sediments are scattered in groups. Mobilik et al., (2017). stated that the distribution of marine debris can occur in waters because there are physical factors that carry debris from one location to another. There are several physical oceanographic factors that play a role in the distribution/movement of debris in the waters, thus causing the accumulation of debris in one place.

2. Dispersion Analysis of Surface Molluscs and Molluses in Sediment

From the data from the sampling of surface molluscs and molluscs in sediments at 21 points, the analysis test for the dispersion of surface molluses and molluses in sediments has a distribution in groups, regularly and randomly, can be seen in (Table 4 and Table 5).

Table 4. Results of Dispersion Index Analysis per Surface Animal Type

\begin{tabular}{|l|l|l|l|l|}
\hline Dispersion Test & Variance & Mean & I & Description \\
\hline Gafrarium pectinatum & 9.7 & 5.2 & 1.8 & Group \\
\hline Anadara antiquata & 0.0 & 0.0 & 0 & Flocking \\
\hline Nerita undata & 1.9 & 1.1 & 1.6 & Group \\
\hline Cheritidea djadjarensis & 279.8 & 13.0 & 21.5 & Group \\
\hline
\end{tabular}

Table 5. Results of Dispersion Index Analysis per Animal Type in Sediment

\begin{tabular}{|l|l|l|l|l|}
\hline Dispersion Test & Variance & Mean & I & Description \\
\hline Gafrarium pectinatum & 44.6 & 8.1 & 5.4 & Group \\
\hline Anadara antiquata & 0.4 & 0.3 & 1.2 & Group \\
\hline Cypraea annulus & 0.0 & 0.0 & 0 & Flocking \\
\hline Nassarius reticulatus & 0.2 & 0.1 & 1.3 & Group \\
\hline Nerita undata & 1.8 & 1.7 & 1.0 & Group \\
\hline Cheritidea djadjarensis & 31.4 & 11.2 & 2.8 & Group \\
\hline
\end{tabular}

Hasil analisis dispersi memperlihatkan bahwa jenis hewan permukan dan hewan dalam sedimen yaitu Gafrarium pectinatum, Nerita undata, Cheritidea djadjarensis, Anadara antiquata dan Nassarius reticulatus memiliki nilai dimana I $>1$ sehingga jenis hewan permukaan dan hewan dalam sedimen ini memiliki pola sebaran secara berkelompok. Ode (2017), menyatakan bahwa pola distribusi mengelompok disebabkan 


\section{Eugenius Alfred Renjaan, Dortje Theodora Silubun, Dullah Irwan Latar, Marvin Mario Makailipessy, Megawati Elisabet Juley}

oleh sifat spesies yang bergerombol atau adanya kesamaan habitat sehingga terjadi pengelompokkan di tempat lain yang terdapat banyak bahan makanan.

Hasil analisis dispersi memperlihatkan bahwa jenis hewan permukaan dan hewan dalam sedimen yaitu Anadara antiquata dan Cypraea annulus memiliki nilai dimana I < 1 sehingga jenis hewan ini tersebar secara teratur. Hamidah $d k k$., (2016) bahwa pola sebaran merata terjadi karena adanya persaingan antara individu dengan individu yang lainnya didalam suatu ekosistem, sehingga mendorong pembagian ruang hidup secara merata.

Menurut Putra et al., (2018), menyatakan bahwa persebaran populasi organisme di alam umumnya mempunyai persebaran mengelompok dan sangat jarang sekali ditemukan dalam pola seragam (merata). Braz et al., (2015) menyatakan bahwa faktor penyebaran populasi dapat disebabkan karena dorongan mencari makanan, menghindarkan diri dari predator, pengaruh iklim, terbawa air/angin. Menurut Zarkasyi $d k k$. (2016) kondisi lingkungan sangat mempengaruhi pola distribusi dan kepadatan spesies yang berada di zona intertidal.

3. Independent Test Samples of Surface Sea Debris Density and Deep Sea Debris Density Sediment.

The results of the Independent Samples t Test analysis of the density of surface marine debris and the density of marine debris in sediments have a significant (significant) difference where the $t$ value is 7,540 > t table 2.101 with a sig value of 0.000 $<0.05$.

Table 6. Test Analysis (t) Density of Surface Sea Debris and Deep Sea Debris Sediment

\begin{tabular}{|c|c|c|c|c|c|}
\hline & $\begin{array}{l}\text { kepatabangunglaut } \\
\text { dalam sefimen }\end{array}$ & N & Hean & Ste Deviation & $\begin{array}{c}\text { St1 Emror } \\
\text { Vean }\end{array}$ \\
\hline \multirow[t]{2}{*}{$\begin{array}{l}\text { Hasil kepaidan pung } \\
\text { lautpemukaan }\end{array}$} & $\begin{array}{l}\text { kepatatanoting laut } \\
\text { pamuaran }\end{array}$ & 21 & & cos:410129 & orcenjelog \\
\hline & $\begin{array}{l}\text { hepatatan ouing lait } \\
\text { dalam sedmen }\end{array}$ & 21 & $021124: 28$ & 0018604221 & 0xc1924239 \\
\hline
\end{tabular}

\begin{tabular}{|c|c|c|c|c|c|c|c|c|c|c|}
\hline & & \multicolumn{2}{|c|}{$\begin{array}{c}\text { Leiena's Testfur Equalin af } \\
\text { Vaiances }\end{array}$} & \multicolumn{7}{|c|}{ tiestiarEsualy of Warns } \\
\hline & & \multirow[b]{2}{*}{$F$} & \multirow[b]{2}{*}{$3 i \frac{2}{2}$} & \multirow[b]{2}{*}{$t$} & \multirow[b]{2}{*}{ df } & \multirow[b]{2}{*}{ Sig $\{2$ tal $=0$} & \multirow{2}{*}{$\begin{array}{c}\text { Vean } \\
\text { Dfrerence }\end{array}$} & \multirow{2}{*}{$\begin{array}{l}\text { Sid Emer } \\
\text { Dfferencs }\end{array}$} & \multicolumn{2}{|c|}{$\begin{array}{l}\text { 958 Curfidensa htenal of the } \\
\text { Ofference }\end{array}$} \\
\hline & & & & & & & & & Laner & Upper \\
\hline $\begin{array}{l}\text { Hasil kepatatan puing } \\
\text { lautpemukaan }\end{array}$ & $\begin{array}{l}\text { Equalyariatcas } \\
\text { assumat }\end{array}$ & 20.963 & 001 & 7,540 & 4 & 938 & 0059663462 & 0069276391 & [05]506959 & .0268329564 \\
\hline & $\begin{array}{l}\text { Equalvariancas nat } \\
\text { assumat }\end{array}$ & & & 7.540 & 21.804 & 038 & 0015603462 & anco236391 & 1051469256 & ouseg27eg? \\
\hline
\end{tabular}

The density of surface marine debris and marine debris in sediments has significant differences because the distribution of marine debris is influenced by natural factors or human activities. Juliandri et al, 2020) which states that the distribution of marine debris can be influenced by natural factors or human activities. most of the plastic debris in the oceans, especially in densely populated coastal areas, enters through shipping and fishing activities, as well as industrial waste which is piped and flows into rivers. The results of the statistical test showed a significant level or had a difference between the density of surface marine debris and the density of marine debris in the sediment where the $t$ value was 7,540 > the $t$ table value was 2.101 with a sig value of $0.000<0.05$. 
(Ghozali, 2016) states that the $\mathrm{t}$ statistical test shows how far the influence of one explanatory or independent variable individually in explaining the variation of the dependent variable and is used to determine whether or not there is an influence of each independent variable individually on the dependent variable. The test was carried out using a significance level of $0.05(=5 \%)$. $\mathrm{H} 1$ is accepted if $\mathrm{t}$ count $>t$ table for $=5 \%$.

4. Test Samples Independent of Surface Animal Density and Animal Density in Sediment.

The results of the Independent Samples t Test analysis of the density of surface animals and animals in sediments have a significant (significant) difference where the $t$ count value is $5,005>\mathrm{t}$ table 2.101 with a sig value of $0.000<0.05$.

Table 7. Test Analysis (t) Density of Surface Animals and Density of Animals in

Sediment

Ginup Sitsisios

\begin{tabular}{|c|c|c|c|c|c|}
\hline & 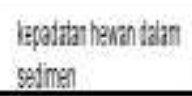 & 11 & Vean & 9410 Dixijon & 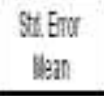 \\
\hline \multirow[t]{2}{*}{ 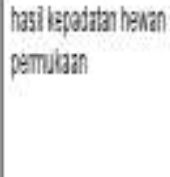 } & $\begin{array}{l}\text { Ieroditan hasen } \\
\text { pemugan }\end{array}$ & 21 & 10102881 & 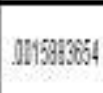 & (2003460)18 \\
\hline & $\begin{array}{l}\text { Iepoithan hanen idant } \\
\text { sedmen }\end{array}$ & 21 & coostos: & movicos? & cond13545 \\
\hline
\end{tabular}

tedependear Sarates Test

\begin{tabular}{|c|c|c|c|c|c|c|c|c|c|c|}
\hline & \multicolumn{2}{|c|}{ 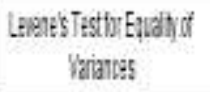 } & \multicolumn{7}{|c|}{ fessturequaly oll:ans } \\
\hline & & \multirow[b]{2}{*}{ f } & \multirow[b]{2}{*}{ Sig } & \multirow[b]{2}{*}{1} & \multirow[b]{2}{*}{ if } & \multirow[b]{2}{*}{ Sif (2iled) } & \multirow{2}{*}{$\begin{array}{c}\text { Hash } \\
\text { Dfenenge }\end{array}$} & \multirow{2}{*}{ 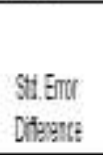 } & \multicolumn{2}{|c|}{ 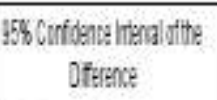 } \\
\hline & & & & & & & & & Liner & Upper \\
\hline \multirow[t]{2}{*}{ 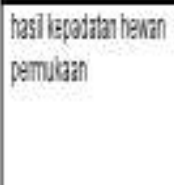 } & $\begin{array}{l}\text { Evud aranes } \\
\text { acsined }\end{array}$ & 15691 & mo & 5005 & 40 & ano & 031331005 & 1003468442 & corn:249413 & 032476697 \\
\hline & $\begin{array}{l}\text { Elud rizanesnt } \\
\text { assined }\end{array}$ & & & 5005 & 200861 & mo & 01733itos & $1004684+43$ & 0011125745 & 002469465 \\
\hline
\end{tabular}

The density of surface animals and animals in sediments has a significant difference, this happens because there are several factors and environmental conditions that support the distribution of molluscs at the sampling location. Sukawati et al., (2018) which states that a community with supportive environmental conditions will lead to the formation of a large number of species with an even abundance. This causes the diversity in the community to be high. However, if in a community with unfavorable environmental conditions, it will tend to consist of a small number of abundant species, only a few species can survive in these environmental conditions, so that these species dominate over other species that cannot survive.

The test results show a significant level or have a significant difference between the density of surface animals and the density of animals in the sediment where the tcount value is $5.005>$ the $t$-table value is 2.101 with a sig value of $0.000<0.05$.

(Ghozali, 2016:99) states that the t statistical test shows how far the influence of one 


\section{Eugenius Alfred Renjaan, Dortje Theodora Silubun, Dullah Irwan Latar, Marvin Mario Makailipessy, Megawati Elisabet Juley}

explanatory or independent variable individually in explaining the variation of the dependent variable and is used to determine whether or not there is an influence of each independent variable individually on the dependent variable. The test was carried out using a significance level of $0.05(=5 \%)$. H1 is accepted if $t$ count $>t$ table for $=5 \%$.

5. Correlation of Surface Plastic Debris Density and Gafrarium pectinatum on Sediment Surfaces

The results of the analysis of the density of surface plastic marine debris with Gafrarium pectinatum have a relationship where the value of $r$ count is $0.453 *>r$ table 0.433 with a sig value of $0.039<0.05$ where the strength of the correlation according to de Vaus interprets that the relationship is moderate.

Table 8. Analysis of Surface Plastic Debris Density and Gafrarium pectinatum on Sediment Surfaces..

Correlations

\begin{tabular}{|ll|r|r|}
\hline & & $\begin{array}{r}\text { Kepadatan_p } \\
\text { uing_laut_pla } \\
\text { stik_permuka } \\
\text { an }\end{array}$ & $\begin{array}{c}\text { Gafrarium_pe } \\
\text { ctinatum }\end{array}$ \\
\hline Kepadatan_puing_laut_plastik_permukaan & Pearson Correlation & 1 & $.453^{n}$ \\
& Sig. (2-tailed) & 21 & .039 \\
& $\mathrm{~N}$ & $.453^{*}$ & 21 \\
\hline Gafrarium_pectinatum & Pearson Correlation & .039 & 1 \\
& Sig. (2-tailed) & 21 & 21 \\
\hline
\end{tabular}

${ }^{\star}$. Correlation is significant at the 0.05 level (2-tailed).

Gafrarium pectinatum on the surface of the sediment is getting more and more, when the surface plastic marine debris is getting denser this happens based on where to live and how to get food from the Gafrarium pectinatum species. Baron and Clavier (2008) stated that Gafrarium pectinatum prefers habitats with sandy bottom substrates to muddy sediments on the bottom surface of the substrate, this is related to the behavior of biota either to obtain food with a filter feeder or to dig holes to avoid themselves from predators. In accordance with their nature, Bivalves prefer habitats with relatively smooth substrates. This is related to feeding behavior where almost all types of Bivalves have properties as filter feeders. Filtering of food from the substrate more often occurs on substrates that have a fine texture such as mud substrates. On coarser substrates, such as sand, gravel or coarser ones, it is more difficult for Bivalves to filter food from these types of substrates (Nurmiati, Sirih, \& Parakkasi, 2016).

The correlation analysis carried out shows that the value of $r=0.453 *$ where in the correlation if the result of $\mathrm{r}$ is found to be positive then the two variables have a unidirectional relationship, meaning that if the $\mathrm{X}$ variable is high then the $\mathrm{Y}$ value will be high and vice versa, if the result is mines, it means that if the $X$ value is high then the value is high. Y will decrease (Budiarta, Ginting, \& Simarmata, 2020).

Pearson correlation analysis (correlate bivariate) was used to determine the linear relationship between one variable and another. The data used is interval or ratio scale. The correlation value ( $r$ ) is 0 to 1 , the closer to 1 the stronger the relationship. On the other hand, the closer the value to 0 , the weaker the relationship (Priyanto, 2013).

This correlation analysis is one type of inferential statistics, so it is necessary to have a hypothesis in formulating conclusions from the results of data analysis. The 
hypothesis is a temporary answer to the formulation of the problem stated in the form of a statement sentence (Sugiyono, 2017).

\section{CONCLUSION}

Based on the results of the study, several conclusions were obtained, namely: The density of surface marine debris and the density of marine debris in sediments has a significant (significant) difference where the $t$ value is $5,005>t$ table 2.101 with a sig value of $0.000<0.05$. The density of surface animals and the density of animals in the sediment has a significant difference (significantly) where the value of $t$ count is $5.005>t$ table 2.101 with a sig value of $0.000<0.05$. The density of marine plastic debris on the surface with Gafrarium pectinatum has a correlation where the calculated $r$ value is $0.453^{*}>\mathrm{r}$ table 0.433 with a sig value of $0.039<0.05$ where the strength of the correlation according to D.A de Vaus 2002 Interprets that the relationship is moderate. Dispersion of surface marine debris and marine debris in sediments is scattered in groups. Dispersion per surface animal type; Gafrarium pectinatum, Nerita nndata and Cerithidea jadjarensis are scattered in groups while Anadara antiquata is distributed regularly. Dispersion per animal species in sediments; Gafrarium pectinatum, Nassarius reticulatus, Nerita undata and Cerithidea djadjarensis are scattered in groups, while Anadara antiquata is distributed regularly and Cypraea annulus is randomly distributed.

\section{REFERENCES}

Beaumont, Nicola J., Aanesen, Margrethe, Austen, Melanie C., Börger, Tobias, Clark, James R., Cole, Matthew, Hooper, Tara, Lindeque, Penelope K., Pascoe, Christine, \& Wyles, Kayleigh J. (2019). Global ecological, social and economic impacts of marine plastic. Marine Pollution Bulletin, 142, 189-195.

Boucher, Julien, \& Friot, Damien. (2017). Primary microplastics in the oceans: a global evaluation of sources (Vol. 10). Iucn Gland, Switzerland.

Budiarta, Kustoro, Ginting, Sugianta Ovinus, \& Simarmata, Janner. (2020). Ekonomi dan Bisnis Digital. Yayasan Kita Menulis.

Candri, Dining Aidil, Junaedah, Baiq, Ahyadi, Hilman, \& Zamroni, Yuliadi. (2018). Keanekaragaman Moluska pada Ekosistem Mangrove di Pulau Lombok. BioWallacea Jurnal Ilmiah Ilmu Biologi, 4(2), 88-93.

Ghozali, I. (2016). Aplikasi Analisis Multivariete Denagn Program IBM SPSS. Edisi 8. Badan Penerbitan Universitas Diponegoro. Semarang.

Jambeck, Jenna R., Geyer, Roland, Wilcox, Chris, Siegler, Theodore R., Perryman, Miriam, Andrady, Anthony, Narayan, Ramani, \& Law, Kara Lavender. (2015). Plastic waste inputs from land into the ocean. Science, 347(6223), 768-771.

Mortillaro, N. (2017). Humans Have Produced 8.3 Billion Tonnes of Plastic, Researchers Say.[online] CBC News 19 July.

Nurmiati, Nurmiati, Sirih, H. M., \& Parakkasi, Parakkasi. (2016). Identifikasi jenis-jenis gastropoda dan bivalvia di Pantai Lowu-Lowu Kecamatan LeaLea Kota Baubau. AMPIBI: Jurnal Alumni Pendidikan Biologi, 1(3), 56-60. 
Pratiwi, Made Ayu, \& Ernawati, Ni Made. (2016). Analisis kualitas air dan kepadatan moluska pada kawasan ekosistem mangrove, Nusa Lembongan. Journal of Marine and Aquatic Sciences, 2(2), 67-72.

Priyanto, Duwi. (2013). Mandiri Belajar Analisis Data Dengan SPSS: Plus Tips Mengerjakan Tugas Akhir, Skripsi, dan Tesis. Cet.

Sugiyono. (2017). metode penelitian kuantitatif, kualitatif dan $R \& D$. Bandung: Alfabeta CV.

Purwaningrum, Pramiati. (2016). Upaya mengurangi timbulan sampah plastik di lingkungan. Indonesian Journal of Urban and Environmental Technology, $8(2), 141-147$.

Renjaan, Eugenius Alfred, Silubun, Dortje T., Latar, Dullah I., \& Makailipessy, Marvin. (2020). Beach orientation and exposure accumulate types of marine debris on the coast of Dullah Island, kei archipelago, Indonesia. IOP Conference Series: Earth and Environmental Science, 517(1), 12015. IOP Publishing.

Triwiyanto, Komang, Suartini, M. N., \& Subagio, N. J. (2015). Keanakeragaman Moluska di Pantai Serangan Desa Serangan Kecamatan Denpasar Selatan Bali. Jurnal Biologi, 19(2), 63.

Wang, Jundong, Tan, Zhi, Peng, Jinping, Qiu, Qiongxuan, \& Li, Meimin. (2016). The behaviors of microplastics in the marine environment. Marine Environmental Research, 113, 7-17. 